Article

\title{
Sustainable Water Supply Systems Management for Energy Efficiency: A Case Study
}

\author{
Izabela Zimoch $^{1, *}$, Ewelina Bartkiewicz ${ }^{1}$, Joanna Machnik-Slomka ${ }^{2}$, Iwona Klosok-Bazan ${ }^{3} \mathbb{D}$, Adam Rak $^{4} \mathbb{D}$ \\ and Stanislav Rusek 5
}

check for updates

Citation: Zimoch, I.; Bartkiewicz, E.; Machnik-Slomka, J.; Klosok-Bazan, I.; Rak, A.; Rusek, S. Sustainable Water Supply Systems Management for Energy Efficiency: A Case Study. Energies 2021, 14, 5101. https:// doi.org/10.3390/en14165101

Academic Editor: Helena M. Ramos

Received: 11 June 2021

Accepted: 8 August 2021

Published: 19 August 2021

Publisher's Note: MDPI stays neutral with regard to jurisdictional claims in published maps and institutional affiliations.

Copyright: (c) 2021 by the authors. Licensee MDPI, Basel, Switzerland. This article is an open access article distributed under the terms and conditions of the Creative Commons Attribution (CC BY) license (https:// creativecommons.org/licenses/by/ $4.0 /)$.
1 Faculty of Energy and Environmental Engineering, Institute of Water and Wastewater Engineering, Silesian University of Technology, Konarskiego 18, 44-100 Gliwice, Poland; ewelina.bartkiewicz@polsl.pl

2 Faculty of Organization and Management, Institute of Management and Logistics, Silesian University of Technology, Roosevelt 26, 41-800 Zabrze, Poland; joanna.machnik-slomka@polsl.pl

3 Department of Thermal Engineering and Industrial Facilities, Faculty of Mechanical Engineering, Opole University of Technology, Mikolajczyka 5, 45-271 Opole, Poland; i.klosok-bazan@po.edu.pl

4 Faculty of Civil Engineering and Architecture, Opole University of Technology, Katowicka 48, 45-061 Opole, Poland; a.rak@po.edu.pl

5 Department of Electrical Power Engineering, Faculty of Electrical Engineering and Computer Science, VSB-Technical University of Ostrava, 70800 Ostrava, Czech Republic; stanislav.rusek@vsb.cz

* Correspondence: izabela.zimoch@polsl.pl

Abstract: A prerequisite for achieving high energy efficiency of water supply systems (understood as using less energy to perform the same task) is the appropriate selection of all elements and their rational use. Energy consumption in water supply systems (WSS) is closely connected with water demand. Especially in the case of oversized water supply systems for which consumers' water demand is at least $50 \%$ less than previously planned and flow velocity in some parts of the system is below $0.01 \mathrm{~m} \cdot \mathrm{s}^{-1}$, this problem of excessive energy consumption can be observed. In the literature, it is difficult to find descriptions and methods of energy management for such a case. The purpose of this study was both an evaluation of the current demand of an oversized WSS and a preliminary technical analysis of the possibility for energy saving. Solutions are presented that resulted in improvements in energy management, thus increasing energy efficiency. The conducted analyses indicate the wide use of numerical, hydraulic models, among others, for the needs of the sustainable oversize water supply systems management in order to improve energy efficiency. Those simulations only give energy consumption results as a first step in the process of decision-making for the modernization process, in which investment costs should be taken into account as a second step. Thus, this paper emphasizes the crucial role of hydraulic models as a good analytical tool used in decision support systems (DSS), especially for large, oversized water supply systems.

Keywords: sustainable development; oversized water supply system; energy management; energy efficiency; water-energy nexus

\section{Introduction}

Due to the increasing importance of sustainable development and environmental awareness of society, effective energy management plays an increasingly important role in the business entities of many industries [1]. Therefore, it is important to measure the impact of the company on the environment and society [2,3]. The literature emphasizes the importance of adequate energy efficiency management that affects water distribution sustainability and water treatment utilities [4]; thus, it is no longer sufficient in the face of today's challenges for the strategy for developing water companies to take only economic considerations into account [5]. Energy efficiency management is associated with a number of benefits fulfilling social, environmental, and financial objectives, such as [6]: a reduction in energy consumption costs, including electricity consumption of water companies; a 
reduction in emissions of pollutants (e.g., $\mathrm{CO}_{2}$ emissions) [7]; increased reliability of water supply system (WSS) operation, as well as optimization of the use of natural resources (including water abstraction) [8]. The above-mentioned activities lead to a reduction of the overall costs of the company in its functioning [9]. An increasing number of water company utilities attach great importance to more responsible energy management [10], which is related, among other things, to the need for more efficient and reliable management of the drinking water supply system [11]. Energy issues have been important priorities for the development of socio-economic policies of most countries in the world for a number of years. The EU defined the strategies governing the implementation of climate and energy framework already in 2008. The first EU climate and energy package was specified at the time as the $3 \times 20$. This package assumes achieving a $20 \%$ reduction in $\mathrm{CO}_{2}$ emissions and obtaining a $20 \%$ share of energy generated by renewable energy sources in total energy production, and increasing the EU energy efficiency by 20\% till 2020 [12-15]. Consistent implementation of the European Green Deal policies is key to realisation of the objectives set in climate and the EU's long-term strategy, to achieve carbon neutrality by 2050 [16]. These strategy includes achieving at least a $40 \%$ reduction in greenhouse gas emissions (from 1990 levels) by the end of 2030, increasing to 32\% the share of renewable energy in the global economy and improving energy efficiency to a level of at least $32.5 \%$ [16]. This is particularly important in the case of oversised WSS, where the decrease of dayly water demand is observed. In this context, striving for increased energy efficiency of the operation and production processes in all areas of the economy including WSS is one of the most important challenges [17]. This is especialy relevent in the case of oversized WSS, where the decrease of daily water demand is observed. To achieve high energy efficiency in these WSS operations, a day-to-day analysis of the interoperability of all components of the system in rapidly changing water demand conditions is necessary.

Innovative solutions, new technologies, and a variety of digital tools that can support the effective management and monitoring of oversized WSS operations have been developed, resulting in the improvement of the hydraulic conditions of the water pipe network and minimization of the risk of secondary water contamination during its distribution. Artificial neural networks (ANNs), numerical hydraulic and quality simulation models (e.g., EPANET, Piccolo, Mike Net, WaterCad) are increasingly used as forecasting tools in relation to water supply issues, including, for example, prediction of disinfection byproducts in the distribution network, modeling chlorine residuals in transported drinking water to the consumer, as well as energy management [18-20]. Energy efficiency management of oversized WSS requires the fulfillment of a number of functions such as planning, organizing, directing, and monitoring at different levels (strategic, operational, tactical). For an energy management system to be effective, a systems approach is required that integrates different functions and interrelated elements [21].

WSS, especially this oversized, absorbs enormous amounts of energy, from raw water abstraction, through treatment processes to transport through the water pipe network to consumers. In 2014, some $4 \%$ of global electricity consumption was used to extract, distribute and treat water and wastewater [22]. Water losses are estimated at 30\%; comparing this value with energy losses [23,24], huge energy losses are obtained. In water supply companies, the largest amounts of energy are consumed at pumping stations [25]. According to Coelho and Andrade-Campos [26], this value represents 80 to $90 \%$ of the total energy consumption in this section of the economy. The amount of energy consumed for pumping depends on many factors, including the quantity of water consumption, dynamic of daily changes of WSS operating conditions, and the pumps' type and age [27].

The main sources of energy loss in pump systems are the incorrect design of the pump installation, incorrect selection of pumps for the installation, lack of modernization of the pumping station (especially in case of decrease of water demand, incorrect hydraulic design of the installation and losses in regulation equipment [27-29]. 
Water supply pumps are selected for optimal working conditions and for the work point of the pump with the highest efficiency, i.e., at the point of BEP (best efficiency point) (Figure 1) [22].

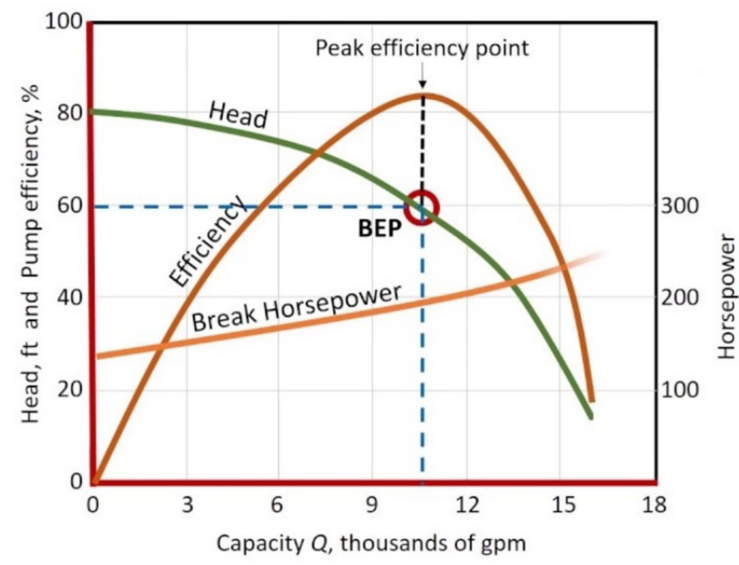

Figure 1. The pumps' hydraulic and efficiency curves [28].

Depending on the type of pump, the BEP point is located in a different place. However, water demand changes over time, which contributes to the operation of pumps at a different point (not always at the highest efficiency point). There are also situations in which pumping systems supply water with too a high head (mostly in large WSS), and the WSS operators are forced to throttle the water pressure using valves. Such activities lead to the waste of electricity. The condition and age of the pumps also have an impact on energy consumption [30]. As it is commonly known, the efficiency of pumps decreases with the time of their operation. After this time, the hydraulic curve decreases in relation to the factory curve, shifting the working point.

To avoid excessive energy consumption, WSS operators plan pump on/off schedules. Three strategies are considered when planning a schedule [31,32]:

- Pressure control: change in pump status (open/closed) along with a change in pressure in the network;

- Level control: change in pump status according to water level variations in storage tanks;

- Time controls: change in pump status at fixed hours of the day.

To reduce energy consumption at pumping stations, various devices for correcting the pressure are used. Such devices include the Variable Frequency Drive (VFD) that controls the speed of pumps, reducing the pressure. The operation of the VFD is presented in Figure 2.

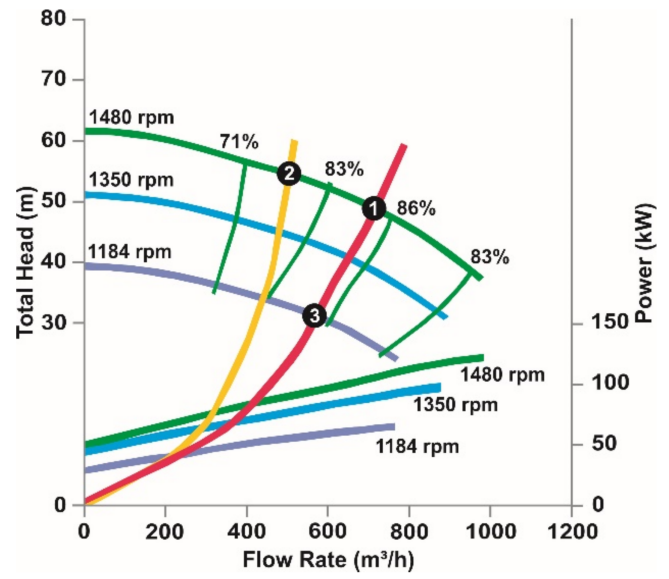

Figure 2. Scheme of VFDs and throttled valves operation, by [33]. 
In the literature, many methods can be highlighted for measuring the efficiency and energy evaluation of WSS. Depending on the top-down or bottom-up approach [33], these methods can be classified as follows [34]:

- Top-down methodologies: focus on efficiency assessments concerning general and diverse processes of the water utility as well as macroeconomic analyses. A frequently used method is a benchmarking or energy audit. Examples of these methods and tools include: ECAM-Energy Performance and Carbon Emissions Assessment and Monitoring Tool; IBNET_the International Benchmarking Network; AquaRating (performance assessment system for water); EPA's Energy Use Assessment Tool; Tools for Energy Footprint Assessment in Urban Water Systems.

- Bottom-up methodologies: are more detailed, based in large part on an energy audit, an energy assessment that focuses on comparing the energy consumed in an ideal system and a real system. Mathematical modeling of operations and physical phenomena and processes are used to develop the ideal network, and the computer model EPANET [35] is often used. Hydraulic analyses are most often calculated using the Darcy-Weisbach equation or the Hazen-Williams equation or based on pump curves (pump efficiency estimation). Many methods based on bottom-up approaches focus on identifying and analyzing the causes of energy losses in water supply systems. Many metrics and indicators can be used to assess energy efficiency.

The reduction of the energy demand for WSS, especially this oversized, should be a priority in building a development strategy for water pipe distribution networks [36,37]. A complex report about energy assessment was presented by the Water Research Foundation, titled “Toolbox for Water Utility Energy and Greenhouse Gas Emission Management" [38]. This comprehensive tool used only for the energy assessment of water utilities was developed by the United States Environmental Protection Agency (US EPA) [39].

The literature on the subject lacks an unambiguous definition of oversized systems with excess production capacity. Therefore, this article assumes that an oversized system is a system in which the demand for water does not exceed $50 \%$ previously planned and flow velocity in some parts of the system is below $0.01 \mathrm{~m} \cdot \mathrm{s}^{-1}$. In the literature, it is difficult to find descriptions and methods of energy management for such systems. The aim of this article is to indicate the possibility of application of commonly used simulation tools, including EPANET software, to the preliminary analysis of various technical solutions of the possibility of energy consumption reducing necessary to supply water to consumers. The subject of the article is a real system for which simple solutions were sought to reduce energy consumption while taking into account the current operating conditions (water demand and required pressure).

The conducted research has shown that energy consumption modeling is a useful tool in the decision support system (DSS), providing arguments for selecting rational technical actions in further analyzes of the investment process (economic, environmental, and social). In addition, the proposed analysis of hydraulic and energy efficiency management can be used in the daily operation of oversized WSS, as main elements of the water safety plans (as introduced by the new directive on water intended for human consumption [40]), if the minimization of the risk of secondary water contamination, is also considered.

\section{Materials and Methods}

\subsection{Research Object}

The research object is a large, oversized WSS that supplies water to over 3 million customers in the industrial region of southern Poland. The area covered by the water pipe network is hilly, with elevation differences equal to $120 \mathrm{~m}$. The system is over $880 \mathrm{~km}$ long, and it is divided into eight major network regions. The water pipe network with a diameter of 500 to 1600 accounts for as much as $93 \%$ of the total length of the water distribution system. The analyzed WSS is a very specific system that delivers water to 48 local municipal distribution subsystems. Municipal distribution subsystems require pressures in the range of 50-100 $\mathrm{m}$ in most cases. This pressure in the main water pipe network guarantees correct 
operating conditions for the local municipal distribution network. The total average water production is about 330,000 cubic meters per day. Due to the closure of large factories and the reduction in water consumption by the production companies, the water production of this analyzed WSS has dropped by about $40 \%$ in the last 10 years. This fact leads to the water retention in the water pipe network reaching about $664,059 \mathrm{~m}^{3}$, which is about $200 \%$ of daily water demand in the analyzed region. The operation of such a specific water supply system also requires the presence of water storage tanks, as indicated by the coefficients of hourly irregularity $\left(0.2<\mathrm{N}_{\mathrm{h}}<2.0\right)$. The WSS is composed (Figure 3 ) of 10 water treatment plants (WTP), 15 pumping stations (PS-nine pumping stations are located in WTP; Table 1), and nine complexes of storage tanks (ST) with a total capacity of over 37,400 cubic meters. Storage tank ST P, ST Q, and ST T are gravity water tanks. The other five storage tanks are located in pumping stations. Only two storage tanks, ST O and ST $\mathrm{U}$, are equipped with pumps (Table 1).

Table 1. Lists of pumping station equipment with pumps.

\begin{tabular}{cccc}
\hline WSS Object & Total Number of Pumps & $\begin{array}{c}\text { Number of Pumps } \\
\text { in Operation }\end{array}$ & Number of Pumps in Operation with \\
Standby Status & 10 \\
\hline WTP B & 12 & 1 & 19 \\
\hline WTP C & 20 & 1 & 3 \\
\hline WTP D & 4 & 1 & 2 \\
\hline WTP E & 3 & 1 & 8 \\
\hline WTP F & 9 & 1 & 1 \\
\hline WTP G & 2 & 1 & 2 \\
\hline WTP H & 3 & 2 & 9 \\
\hline WTP I & 11 & 1 & 4 \\
\hline WTP J & 5 & 1 & 6 \\
\hline PS K & 7 & 3 & 10 \\
\hline PS L & 13 & 2 & 5 \\
\hline PS M & 7 & 2 & 2 \\
\hline PS N & 4 & 1 & 9 \\
\hline ST O & 10 & 1 & 1 \\
\hline ST S & 2 & 21 & 91 \\
\hline SUM & 112 & & \\
\hline
\end{tabular}



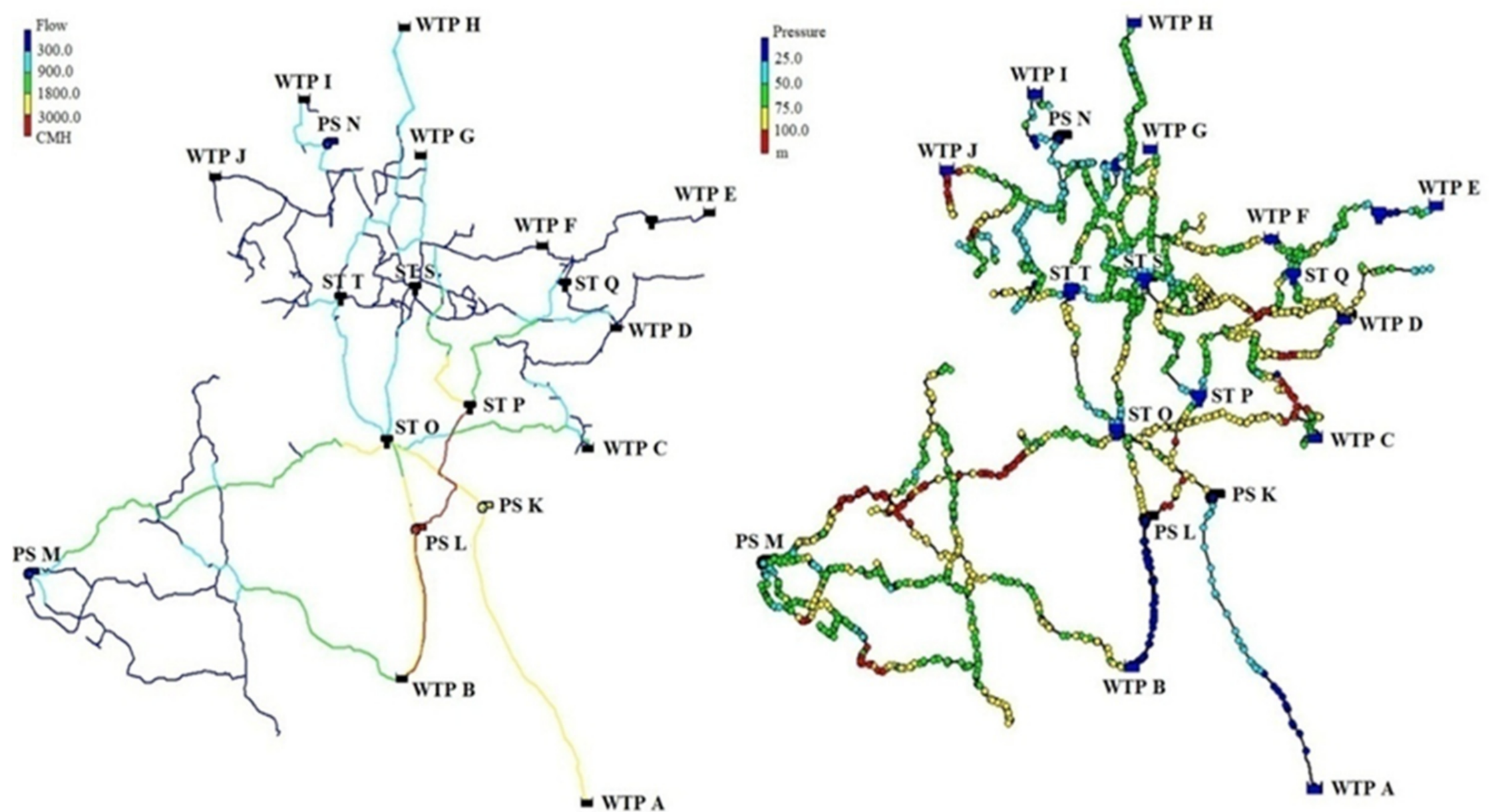

(A)

(B)

Figure 3. WSS scheme with (A) average water flows and (B) average pressure. 


\subsubsection{Water Treatment Plant}

Stations WTP A, WTP B, and WTP C are the largest stations, whose water production accounts for $80 \%$ of the total WSS water production. WTP A provides water to the PS $\mathrm{K}$ (240 $\mathrm{m}$ above sea level) using a gravitational method, which transports water to ST O at $330 \mathrm{~m}$ above sea level. WTP B supplies water in three directions; two of them use a gravitational flow of water to PS L, and the third direction is supplied from the pumping station. PS L supplies two-tank complexes, ST O (330 m above sea level), and ST P (346 $\mathrm{m}$ above sea level). WTP C supplies two directions from the pumping station; the first direction supplies ST O and ST P, while the second supplies a small area in the east. Stations D, E, and F supply the north-eastern area of the system using pumping systems. Their production capacity is $6 \%$ of the total water production. WTP G and WTP H supply the northern area of the network and part of the central area. These stations supply the above-mentioned area by pumping stations, which cooperate with each other based on the given pressures. WTP I and WTP J supply the western area of the network. WTP I transports water in two directions, one of which cooperates with the PS N.

\subsubsection{Pumping Stations}

The analyzed system contains 15 pumping stations, with 112 pumps ( 21 with active status and 91 with standby status, Table 1). Due to the significant reduction in water demand in the Silesian region, most of the pumping stations are significantly oversized. Consequently, pumping stations operate with a high-reliability reserve, which significantly increases their maintenance costs. Table 2 lists the parameters of active pumps. Nine pumping stations are controlled by a VFD (marked in Table 2 with *), and four PS are controlled by a throttle valve ( $\beta$ mark in Table 2 ). The pump on/off controls and VFD controls are made depending on the current network parameters.

Table 2. Pump parameters.

\begin{tabular}{|c|c|c|c|}
\hline WSS Object/Pump Number & Pump Type & Flow $Q\left(\mathrm{~m}^{3} / \mathrm{h}\right)$ & Head H (m) \\
\hline \multicolumn{4}{|c|}{ WTP B } \\
\hline Pump no. 1 & Vertical & 1000 & 75 \\
\hline Pump no. 2 & Vertical & 1500 & 75 \\
\hline \multicolumn{4}{|c|}{ WTP C $\beta$} \\
\hline Pump no. 1 & Horizontal & 1800 & 87 \\
\hline \multicolumn{4}{|c|}{ WTP D * } \\
\hline Pump no. 1 & Horizontal & 1400 & 86 \\
\hline \multicolumn{4}{|c|}{ WTP E* } \\
\hline Pump no. 1 & Horizontal & 360 & 55 \\
\hline \multicolumn{4}{|c|}{$\mathrm{WTP} \mathrm{F}^{*}, \beta$} \\
\hline Pump no. 1 & Vertical & 1450 & 96 \\
\hline \multicolumn{4}{|c|}{ WTP G * } \\
\hline Pump no. 1 & Horizontal & 1200 & 90 \\
\hline \multicolumn{4}{|c|}{ WTP H* } \\
\hline Pump no. 1 & Horizontal & 3000 & 100 \\
\hline \multicolumn{4}{|c|}{ WTP I $\beta$} \\
\hline Pump no. 1 & Vertical & 640 & 60 \\
\hline Pump no. 2 & Vertical & 150 & 66 \\
\hline
\end{tabular}


Table 2. Cont.

\begin{tabular}{|c|c|c|c|}
\hline WSS Object/Pump Number & Pump Type & Flow $Q\left(\mathrm{~m}^{3} / \mathrm{h}\right)$ & Head H (m) \\
\hline \multicolumn{4}{|c|}{ WTP J * } \\
\hline Pump no. 1 & Horizontal & 550 & 125 \\
\hline \multicolumn{4}{|c|}{ PS K $\beta$} \\
\hline Pump no. 2 & Horizontal & 2400 & 104 \\
\hline \multicolumn{4}{|c|}{ PS L $\beta$} \\
\hline Pump no. 1 & Horizontal & 1400 & 96 \\
\hline Pump no. 2 & Horizontal & 2400 & 98 \\
\hline Pump no. 3 & Horizontal & 3600 & 115 \\
\hline \multicolumn{4}{|c|}{ PS M* } \\
\hline Pump no. 1 & Horizontal & 240 & 40 \\
\hline Pump no. 2 & Horizontal & 360 & 40 \\
\hline \multicolumn{4}{|c|}{$\mathrm{PS} \mathrm{N}^{*}$} \\
\hline Pump no. 1 & Horizontal & 240 & 65 \\
\hline Pump no. 2 & Horizontal & 240 & 65 \\
\hline \multicolumn{4}{|c|}{$\mathrm{ST} \mathrm{O}^{*}$} \\
\hline Pump no. 1 & Horizontal & 2160 & 52 \\
\hline \multicolumn{4}{|c|}{ ST S* } \\
\hline Pump no. 1 & Horizontal & 240 & 65 \\
\hline
\end{tabular}

Control of pump stations is based on the dependencies as described above. Examples of controls are presented below:

- PS N: If node number 13,545 pressure is below $43 \mathrm{mH}_{2} \mathrm{O}$, then pump number 20,965 status is open; if node number 13,545 pressure is below $40 \mathrm{mH}_{2} \mathrm{O}$, then pump number 20,966 status is open (cascade pumps switching) - pressure control,

- PS L: If tank number 12,989 level is below $4.5 \mathrm{mH}_{2} \mathrm{O}$, then pump number 19,152 status is open, else pump number 19,152 status is closed-level control,

- WTP F: If system clock time $\geq 6$ a.m., and system clock time $\leq 10$ p.m., then pump 21,141 status is open, else pump 21,141 status is closed-time control.

\subsection{Analysis Methodology}

The numerical model was developed based on EPANET 2.0 software. The network graph was exported from the GIS (Geographic Information System) database, while the water demand data for a one-year period (2019) was exported from the available billing databases. Daily water consumption patterns were created from the SCADA (Supervisory Control and Data Acquisition) telemetry system. As this WSS supplies an urban industrial area with a high prevalence of urban areas $(93.8 \%)$, in hydraulic models, different consumption patterns are used depending on how the water is used during the day. Domestic water consumption patterns are characterized by the standard regularity of the occurrence of two peaks of water consumption in the morning and in the evening (Figure 4). 


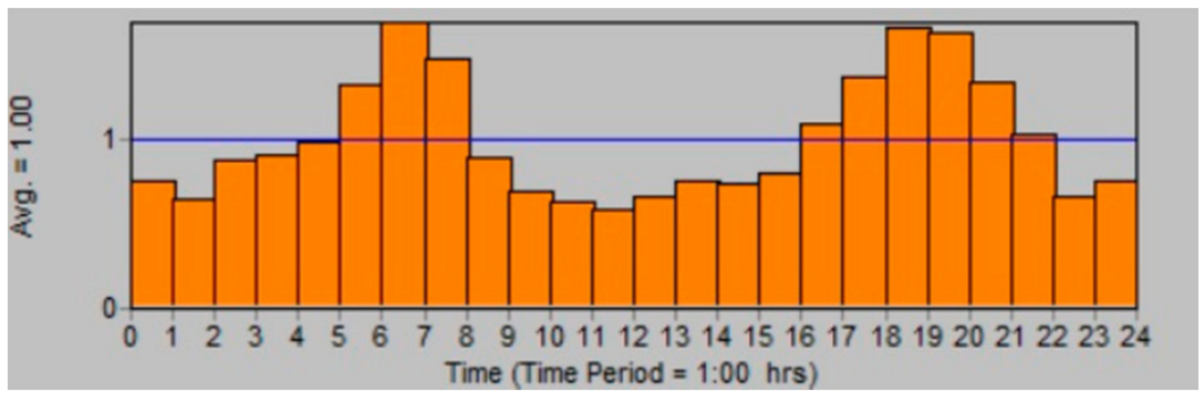

Figure 4. Daily water consumption pattern for a selected domestic customer.

In this region, industrial consumers often collect water over the whole day, contributing to the maintenance of continuously high network pressures at $75-100 \mathrm{mH}_{2} \mathrm{O}$. Figure 5 shows an example of a water consumption pattern for industry characterized by a certain regularity of water intake from morning to night.

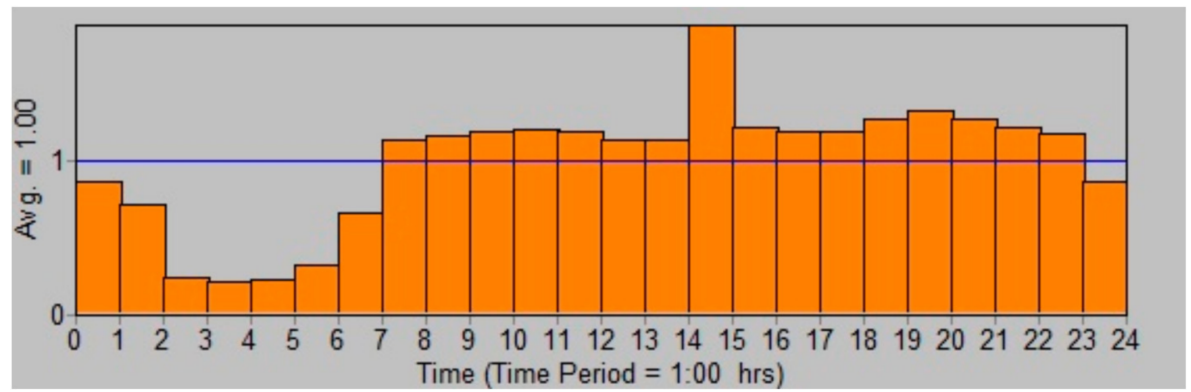

Figure 5. Daily water consumption pattern for a selected industrial customer.

The model was built from 1488 pipes, 1989 nodes, 524 valves, 22 pumps, 4 tanks, and 4 reservoirs. Each of the 22 pumps was assigned an efficiency curve. In order to complete the characterization of the water pipes, the variable absolute roughness of the pipes was assumed in the hydraulic model for each section of the distribution network. In the building model process, both the quality of transported water and the age and type of pipe's material were considered in the evaluation of the variation of pipe roughness over the WSS lifetime. In the case of PVC and PEHD, ductile iron, and steel pipes with cement coating, the value of absolute roughness was assumed at the level from 0.05 to $0.1 \mathrm{~mm}$ (PEHD and PVC) and from 0.4 to $0.6 \mathrm{~mm}$ (ductile iron and steel with coating) respectively. However, for cast iron and steel pipes (without coating), the equivalent roughness was determined from the following formula:

$$
k=k_{o}+\alpha \cdot t
$$

where:

$k_{0}$-the roughness of the new pipeline, $\mathrm{mm}$ (for steel and cast iron pipelines assumed $k_{o} \in(0.4 ; 0.6) \mathrm{mm}$;

$\alpha$-annual increment of apparent roughness, depending on water corrosivity and pipeline diameter, $\mathrm{mm}$; the value of alpha coefficient determined from the hydraulic resistance tests of the water network took values in the range from 0.06 to $0.729 \mathrm{~mm} / \mathrm{a}$.

$t$-operation time of the pipeline.

The built hydraulic model is characterized by the variation of unconformable roughness in the range from $0.54 \mathrm{~mm}$ to $59.4 \mathrm{~mm}$. In the process of calibrating the hydraulic model, the range of variation in water pipes' roughness was verified.

The calibration was performed for data from a one-month period (October 2019), while model validation covered a period of three days (24-26 October). Hydraulic calculations were performed using the Darcy-Weisbach equation. The accuracy of the model was 
determined based on plotted correlation plots (from EPANET 2.0 software) and error analysis using Theil's method. The model accuracy was evaluated for the entire water supply network and 21 separate WSS operating zones (Table 3).

Table 3. Results of compliance analyses for the whole water supply system.

\begin{tabular}{|c|c|c|c|c|c|}
\hline & $\begin{array}{c}\text { Number of } \\
\text { Measurements }\end{array}$ & $\begin{array}{c}\text { Average } \\
\text { Measurement Value }\end{array}$ & $\begin{array}{c}\text { Average } \\
\text { Simulation Value }\end{array}$ & $\begin{array}{c}\text { Average Error } \\
(\%)\end{array}$ & Theil \\
\hline Flow $\left(\mathrm{m}^{3} / \mathrm{h}\right)$ & 56 & 974.21 & 1024.69 & 14.11 & 0.01367 \\
\hline Pressure $\left(\mathrm{mH}_{2} \mathrm{O}\right)$ & 118 & 64.23 & 64.65 & 3.70 & 0.00194 \\
\hline
\end{tabular}

For this model, we obtained a high correlation of computed and observed values. For pressure, the match was $99.4 \%$, and for flow, it was $99.0 \%$. The model accuracy was also checked by the determination coefficient $\mathrm{R}^{2}$ (Figure 6), which for both parameters was in the range of $0.9-1.0$, indicating a high adjustment of the predicted parameters. $R^{2}$ takes the value 0.982 for pressure (Figure 6A) and 0.951 for flow (Figure 6B).

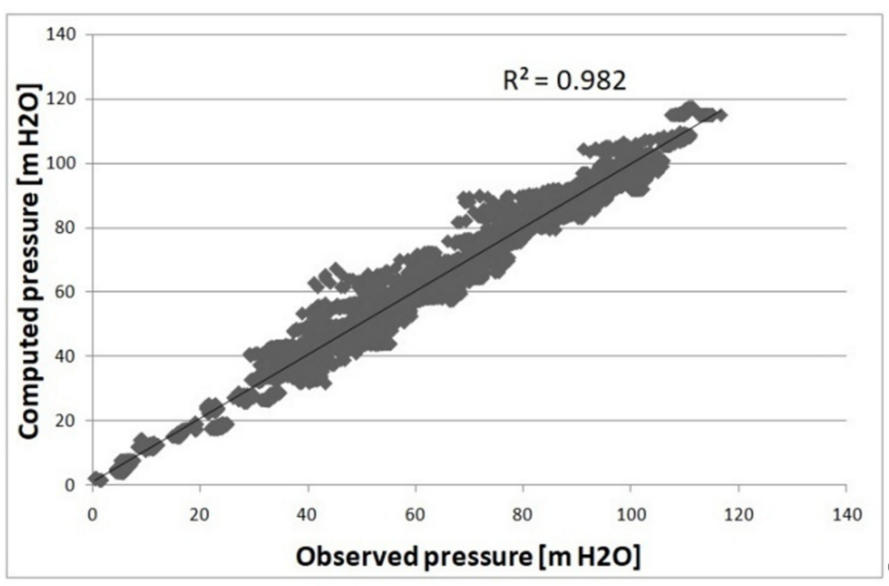

(A)

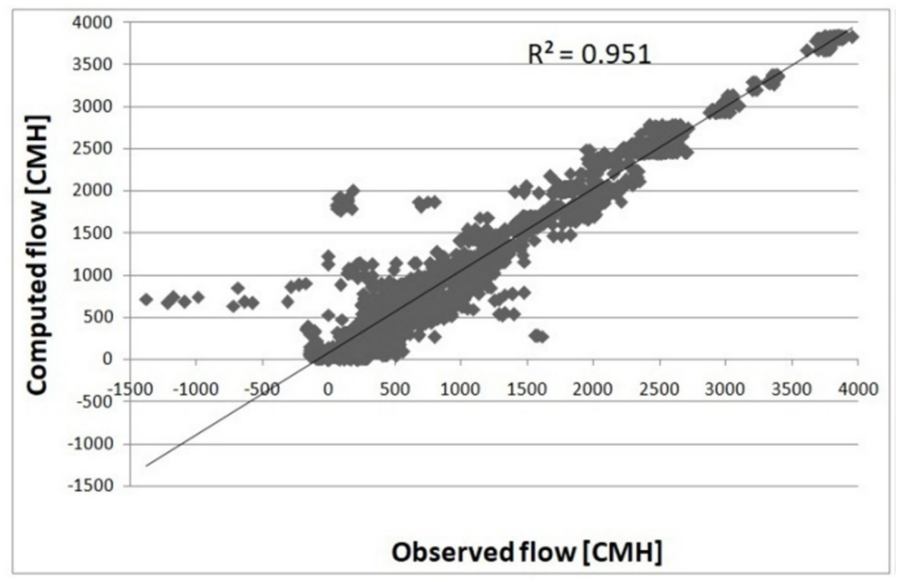

(B)

Figure 6. Correlation plot between the observed and simulated values. (A) - pressure; (B)—flow.

The simulation model was used to calculate the energy analyses of pumping stations' operations. In our study, we have included investigations of energy power, energy efficiency, and energy consumption. Pump power is a measure of the electric power that is needed to operate a pump (or collection of pumps) relative to the volume flow rate. It is not constant for a given pump, but changes with both flow rate and pump pressure [41]. Pump efficiency is defined as the ratio of water horsepower output from the pump to the shaft horsepower input for the pump. Water horsepower is determined by the flow rate and pressure delivered from the pump. The shaft horsepower is delivered to the pump from the power unit, which usually is an electric motor or internal combustion engine. The energy consumption depends on the flow rate. If the energy consumption is measured by the power consumption of the pump motor, the ratio of effective power by the power input gives the efficiency of the pump, including engine efficiency [42].

As part of the conducted studies, three analytical scenarios were considered regarding oversized WSS operation. Scenario no. 1 presented normal operating conditions of analyzed WSS. Scenario no. 2 included the construction of a network storage tank at the highest point of the WSS, while in Scenario no. 3, we considered the use of VFP to control the speed of pumps. The first energy consumption results were obtained for normal system operation (Scenario no. 1). The average energy power was obtained at $6050 \mathrm{~kW}$. In the next step, we attempted to reduce the energy consumption of the analyzed WSS.

In Scenario no. 2, we assumed the inclusion of a new water tank at the highest point of the network and the opening of two valves (Figure 7). The tank was placed on the border of 
two zones, which were connected to the tank. The work includes a pressure tower with a diameter of $40 \mathrm{~m}$ and a volume of $7500 \mathrm{~m}^{3}$. The first open valve was located on the border of the supply zones of WTP J and ST T. The second open valve was located between the supply zones of WTPs C and D. The operating capacity of the storage tank was determined based on the inflow and outflow of water for each hourly interval during a day. The inflow was determined on the basis of water demand in the zone of WTPs J, C, and D. The capacity of the storage tank was determined based on the constant efficiency of the pump during the day. The maximum level of the water table $(6 \mathrm{~m})$ in the storage tank was obtained based on its location and the determined minimum usable volume. The water table varied between 3 and $6 \mathrm{~m}$ during a day, depending on water demand.

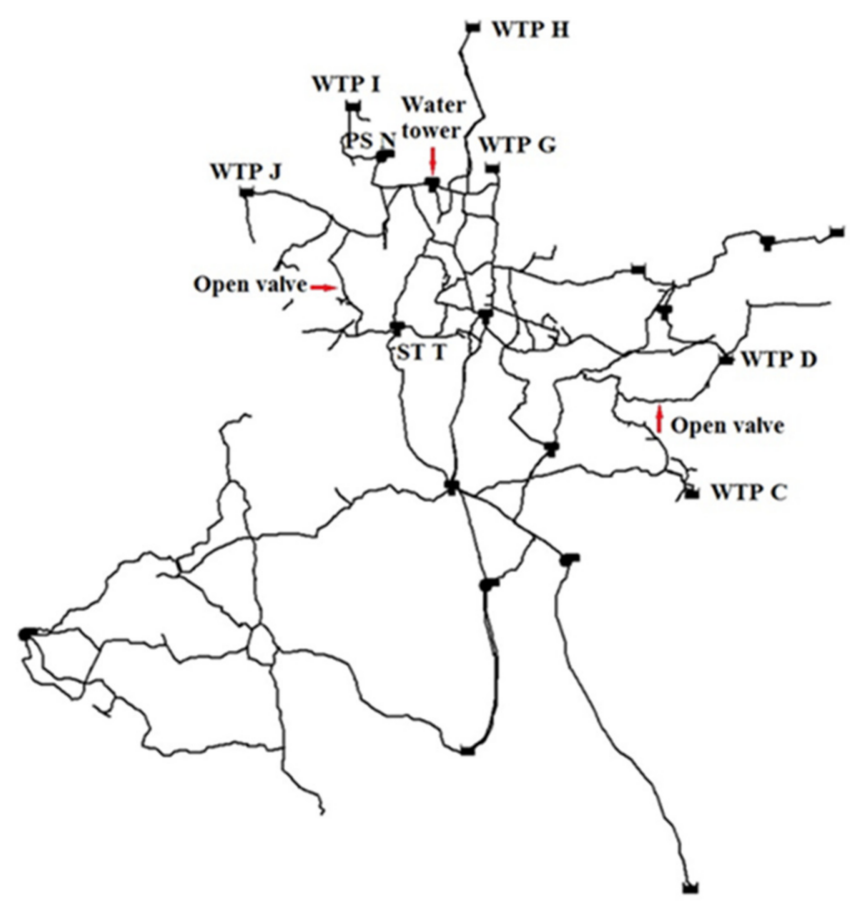

Figure 7. WSS scheme with marked changes for first modification (Scenario no. 2).

In the last simulation (Scenario no. 3), we replaced the throttle valves with VFD devices. The VDP settings have been selected according to the pressure in the WTPs and pressure requirements in the network. Inverters were introduced in the following facilities: WTP C, WTP I, PS M, and PS L. In all simulations, the EPANET 2.0 software was used. An integral part of the study was the calculation of reductions of $\mathrm{CO}_{2}$ emission based on conversion factors recommended by the National Centre for Emissions Management.

\section{Results and Discussion}

The results of the conducted simulations are presented in Tables 4-7. In Scenario no. 1, the total energy consumption was on the level of 998,044 kWh. The highest energy consumption was recorded in PS K and PS L, which consumed almost $55.1 \%$ of the energy used by the whole system. This is connected with the high power of pumps working in those places. The pump power, for the peak efficiency of PS L, was a as high as $1375 \mathrm{~kW}$ (pump no. 3) and $701 \mathrm{~kW}$ (pump no. 1). For PS K, it reached a power level of $841 \mathrm{~kW}$. The lowest energy consumption (5342 kWh) was recorded in ST S. 
Table 4. The results obtained in Scenario 1.

\begin{tabular}{|c|c|c|c|c|}
\hline \multirow{2}{*}{ PS } & $\begin{array}{l}\text { Average Pump } \\
\text { Efficiency }\end{array}$ & $\begin{array}{l}\text { Pump Power for a } \\
\text { Peak Efficiency Point }\end{array}$ & $\begin{array}{l}\text { Operation } \\
\text { Time }\end{array}$ & Energy Consumption \\
\hline & $(\%)$ & $(\mathrm{kW})$ & (h/week) & (kWh) \\
\hline WTP B & 75.0 & 501 & 168 & 54,919 \\
\hline WTP B & 75.0 & 413 & 168 & 55,138 \\
\hline WTP C & 100.0 & 412 & 168 & 66,024 \\
\hline WTP D & 63.3 & 290 & 168 & 40,555 \\
\hline WTP E & 73.5 & 86 & 168 & 13,994 \\
\hline WTP F & 33.2 & 171 & 113 & 14,272 \\
\hline WTP G & 52.3 & 311 & 168 & 46,855 \\
\hline WTP H & 49.3 & 520 & 168 & 67,519 \\
\hline WTP I & 71.7 & 119 & 168 & 15,318 \\
\hline WTP I & 61.4 & 108 & 119 & 11,912 \\
\hline WTP I & 57.3 & 35 & 168 & 5712 \\
\hline WTP J & 70.2 & 154 & 168 & 19,824 \\
\hline PS K & 84.5 & 841 & 168 & 139,675 \\
\hline PS L & 80.2 & 701 & 168 & 116,995 \\
\hline PS L & 81.8 & 1375 & 168 & 230,832 \\
\hline PS M & 40.8 & 44 & 149 & 4276 \\
\hline PS M & 67.0 & 76 & 98 & 7330 \\
\hline PS N & 68.6 & 46 & 168 & 6132 \\
\hline PS N & 68.4 & 42 & 152 & 5548 \\
\hline PS N & 70.8 & 54 & 168 & 8350 \\
\hline ST O & 89.2 & 385 & 168 & 61,522 \\
\hline ST S & 67.1 & 37 & 168 & 5342 \\
\hline & & SUM 998,044 & & \\
\hline
\end{tabular}

Table 5. The results obtained in Scenario no. 2.

\begin{tabular}{|c|c|c|c|c|c|}
\hline \multirow{2}{*}{ PS } & $\begin{array}{l}\text { Average Pump } \\
\text { Efficiency }\end{array}$ & $\begin{array}{l}\text { Pump Power for a Peak } \\
\text { Efficiency Point }\end{array}$ & $\begin{array}{l}\text { Operation } \\
\text { Time }\end{array}$ & $\begin{array}{c}\text { Energy } \\
\text { Consumption }\end{array}$ & $\begin{array}{l}\text { Reduction of Energy } \\
\text { Consumption }\end{array}$ \\
\hline & $(\%)$ & $(\mathrm{kW})$ & (h/week) & (kWh) & $(\%)$ \\
\hline WTP B & 75.0 & 501 & 168 & 54,934 & 0 \\
\hline WTP B & 75.0 & 426 & 168 & 55,151 & 0 \\
\hline WTP C & 100.0 & 413 & 168 & 60,697 & 8 \\
\hline WTP D & 62.6 & 277 & 168 & 42,437 & -5 \\
\hline WTP E & 73.5 & 86 & 168 & 13,991 & 0 \\
\hline WTP F & 39.5 & 169 & 112 & 14,204 & 0 \\
\hline WTP G & 55.7 & 304 & 168 & 48,871 & -4 \\
\hline WTP H & 44.0 & 381 & 168 & 62,580 & 7 \\
\hline WTP I & 70.1 & 74 & 168 & 9314 & 39 \\
\hline WTP I & & & Pump off & & 100 \\
\hline
\end{tabular}


Table 5. Cont.

\begin{tabular}{|c|c|c|c|c|c|}
\hline \multirow{2}{*}{ PS } & $\begin{array}{l}\text { Average Pump } \\
\text { Efficiency }\end{array}$ & $\begin{array}{c}\text { Pump Power for a Peak } \\
\text { Efficiency Point }\end{array}$ & $\begin{array}{l}\text { Operation } \\
\text { Time }\end{array}$ & $\begin{array}{c}\text { Energy } \\
\text { Consumption }\end{array}$ & $\begin{array}{l}\text { Reduction of Energy } \\
\text { Consumption }\end{array}$ \\
\hline & $(\%)$ & $(\mathrm{kW})$ & (h/week) & $(\mathrm{kWh})$ & $(\%)$ \\
\hline WTP I & 57.3 & 35 & 168 & 5712 & 0 \\
\hline WTP J & 70.3 & 154 & 168 & 19,871 & 0 \\
\hline PS K & 84.6 & 845 & 168 & 140,599 & -1 \\
\hline PS L & 79.2 & 525 & 168 & 86,755 & 26 \\
\hline PS L & 81.8 & 1387 & 168 & 230,530 & 0 \\
\hline PS M & 40.9 & 49 & 149 & 4281 & 0 \\
\hline PS M & 67.0 & 77 & 98 & 7340 & 0 \\
\hline PS N & 68.9 & 42 & 168 & 5700 & 7 \\
\hline PS N & 68.9 & 36 & 152 & 5126 & 8 \\
\hline PS N & 72.5 & 53 & 168 & 8261 & 1 \\
\hline ST O & 89.2 & 385 & 168 & 61,520 & 0 \\
\hline \multirow[t]{2}{*}{ ST S } & 68.8 & 37 & 168 & 5201 & 3 \\
\hline & \multicolumn{2}{|r|}{ SUM } & & 943,075 & \\
\hline
\end{tabular}

Table 6. The results obtained in Scenario no. 3.

\begin{tabular}{|c|c|c|c|c|c|}
\hline \multirow{2}{*}{ PS } & $\begin{array}{l}\text { Average Pump } \\
\text { Efficiency }\end{array}$ & $\begin{array}{c}\text { Pump Power for a Peak } \\
\text { Efficiency Point }\end{array}$ & $\begin{array}{l}\text { Operation } \\
\text { Time }\end{array}$ & $\begin{array}{c}\text { Energy } \\
\text { Consumption }\end{array}$ & $\begin{array}{l}\text { Reduction of Energy } \\
\text { Consumption }\end{array}$ \\
\hline & $(\%)$ & $(\mathrm{kW})$ & (h/week) & (kWh) & $(\%)$ \\
\hline WTP B & 75.0 & 501 & 168 & 57,313 & -4 \\
\hline WTP B & 75.0 & 420 & 168 & 57,514 & -4 \\
\hline WTP C & 100.0 & 413 & 168 & 49,090 & 26 \\
\hline WTP D & 65.8 & 277 & 168 & 39,766 & 2 \\
\hline WTP E & 73.7 & 89 & 168 & 14,599 & -4 \\
\hline WTP F & 42.7 & 169 & 112 & 14,146 & 1 \\
\hline WTP G & 55.8 & 301 & 168 & 47,107 & -1 \\
\hline WTP H & 49.5 & 431 & 168 & 67,620 & 0 \\
\hline WTP I & 70.6 & 74 & 168 & 9190 & 40 \\
\hline WTP I & & & Pump off & & 100 \\
\hline WTP I & 57.3 & 35 & 168 & 5715 & 0 \\
\hline WTP J & 70.3 & 154 & 168 & 19,869 & 0 \\
\hline PS K & 84.7 & 845 & 168 & 140,314 & 0 \\
\hline PS L & 78.9 & 525 & 168 & 86,777 & 26 \\
\hline PS L & 80.9 & 1347 & 168 & 222,886 & 3 \\
\hline PSM & & & Pump off & & 100 \\
\hline PS M & 66.9 & 73 & 98 & 6896 & 6 \\
\hline PS N & 68.9 & 42 & 168 & 5700 & 7 \\
\hline PS N & 68.9 & 36 & 152 & 5128 & 8 \\
\hline PS N & 72.7 & 53 & 168 & 8261 & 1 \\
\hline ST O & 89.3 & 386 & 168 & 61,651 & 0 \\
\hline \multirow[t]{2}{*}{ ST S } & 68.8 & 37 & 168 & 5342 & 0 \\
\hline & \multicolumn{2}{|r|}{ SUM } & & 924,885 & \\
\hline
\end{tabular}


Table 7. Comparison of simulation results.

\begin{tabular}{ccccc}
\hline & $\begin{array}{c}\text { Energy } \\
\text { Consumption }\end{array}$ & Reduction of Energy Consumption & $\begin{array}{c}\text { Environmental Effect } \\
\text { Reduction in CO } \mathbf{~}_{\mathbf{2}} \text { Emissions * }\end{array}$ \\
\hline Scenario 1 & $\mathbf{( k W h )}$ & $\mathbf{( k W h )}$ & $\mathbf{( \% )}$ & $\mathbf{( k g ~ C O}_{\mathbf{2}} \mathbf{)}$ \\
Scenario 2 & 998,044 & - & - & 45,696 \\
Scenario 3 & 943,075 & 54,969 & 5.5 & 60,817 \\
\hline
\end{tabular}

* conversion factors recommended by the National Centre for Emissions Management (KOBIZE) were applied.

For Scenario no. 1, the pump efficiency changed from $33.2 \%$ (WTP F) to $100 \%$ (WTP C). The range of the pump efficiency for Scenario no. 2 was between 39.5\% (WTP F) and 100\% (WTP C), while for Scenario no. 3, it had values between 42.7\% (WTP F) and 100\% (WTP C). The obtained study results show the possibility of improving the effectiveness of the operational procedure of the water pipe network, based on the analysis of both pump operation time and energy consumption [43] (presented the proposed Scenario no. 2 and no. 3).

The introduction of the water tower resulted in reduced water production in WTP I and WTP H, but increased water production in WTP G. The reduction in water production in WTP I resulted in the switching off of the pump, thus reducing the energy consumption (by about $5 \%$ ) of the pumping at PS N. After opening the valve on the border of the WTP J and ST T zone, water production in WTP J was reduced, and the outflow of water from the tanks increased, which is supplied by WTP A and B (through ST O), which caused a slight increase in energy consumption (about $1 \%$ ) at PS K, and about $8 \%$ reduce at PS L. The opening of the second valve resulted in a reduction in water production in WTP C and increased water production in WTP D, which is beneficial due to the age and wear of pumps in WTP D.

The introduced changes in the structure and operation of the network caused a reduction in energy consumption by the pumping stations. For the first modification (Scenario no. 2), over 5.5\% (Table 7) of the global reduction in energy consumption was obtained (Table 6), with the largest effects for WTP I-pump no. $1(100 \%)$ and pump no. 2 $(39 \%)$ as well as PS L (26\%) (Table 5). This confirms the theses presented by Rego et al. [44] that energy consumption in water distribution systems, one of the major expenses for local governments today, can be decreased significantly by the optimization of water network operations. The final results of Scenario no. 2 achieved a lower range of the values presented in the literature [44], where energy cutbacks were noted as between $10 \%$ and $50 \%$ according to control strategies and optimized operations, and they may even reach $70 \%$ with frequency inverters instead of throttle valves.

The conducted analysis of energy efficiency for Scenario no. 2 (the first modification) shows that the optimization of the operation of the entire WSS, taking into account the spatial distribution of users, water sources, and storage reservoirs, significantly influenced energy consumption.

In Scenario no. 2, the efficiency of the whole analyzed WSS's pumping system slightly increased by $0.6 \%$ as compared to Scenario no. 1 . It reached the value of $69 \%$, but we observed changes in particular pumps. The largest increase in energy efficiency (by 6.3\%) was recorded for the pump in WTP F, the energy efficiency of which increased to $39.5 \%$. Additionally, for the power pump in WTP G, there was a significant increase in energy efficiency, corresponding to $3.4 \%$ (to the level of $55.7 \%$ ), while for seven pumps, this increase did not exceed $2 \%$. It should be emphasized that the proposed technological solution in Scenario no. 2 resulted in a significant decrease in the energy efficiency of the pumps in WTP H and WTP I by 5.3\% and 1.6\%, respectively. This fact proves that the construction of a reservoir in WSS is an acceptable technical solution to improve the method of energy management. Therefore, modeling with the use of EPANET software is the starting point for determining the best solutions to minimize energy consumption. Similar research results presented in the literature [45,46] indicate that the spatial assessment of energy efficiency of the entire WSS should take into account both the current energy consumption 
and the efficiency of its use. Such studies are used to establish a relationship between the value of the quality indicator (ratio of energy used to minimum energy) and the energy reduction possibilities. This methodical approach to assessing energy consumption allows the water supplier to assess how economically the WSS uses its energy.

For the second modification (Scenario no. 3), over 7.2\% (Table 7) of the global reduction in energy consumption was obtained; the largest reduction in energy consumption was obtained for WTP I (100\%, pump is off) and PS M (100\%, pump is off). Additionally, the following results were obtained: WTP I (40\%), WTP C, and PS L (26\%). These results are presented in Table 6 . The activities carried out in the second modification allowed a reduction in energy consumption without interfering with the amount of water supplied by the stations in which the VFDs were introduced. The conducted simulations show that the pumping systems' operation strategy was carried out in an incompletely correct manner. Throttling the pumps with gate valves led to an excess of energy consumption, as exemplified by WTP I, WTP C, and PS L.

The reduction in energy consumption was correlated with an improvement in the energy efficiency of the existing pumping system (Table 7). The introduction of regulation via VFP to control the pump speed resulted in efficiency improvements for twelve pumps. The effects were translated into a reduction of carbon dioxide emissions, which for Scenario 2 equaled 45,696 $\mathrm{kg} \mathrm{CO}_{2}$, while for Scenario 3, the reduction was $60,817 \mathrm{~kg} \mathrm{CO}_{2}$.

The greatest effect of the increase in efficiency (by $9.5 \%$ to the level of $42.7 \%$ ) was recorded by WTP F. For the remaining eleven pumps, the energy efficiency improvements did not exceed 3.5\%. In Scenario no. 3, only four pumps showed a deterioration in efficiency, which did not exceed $2 \%$ (range of changes from $-0.1 \%$ to $-1.3 \%$ ). The change in pump efficiency in the analyzed pumps vs. Scenario no. 1 is shown in Figure 8.

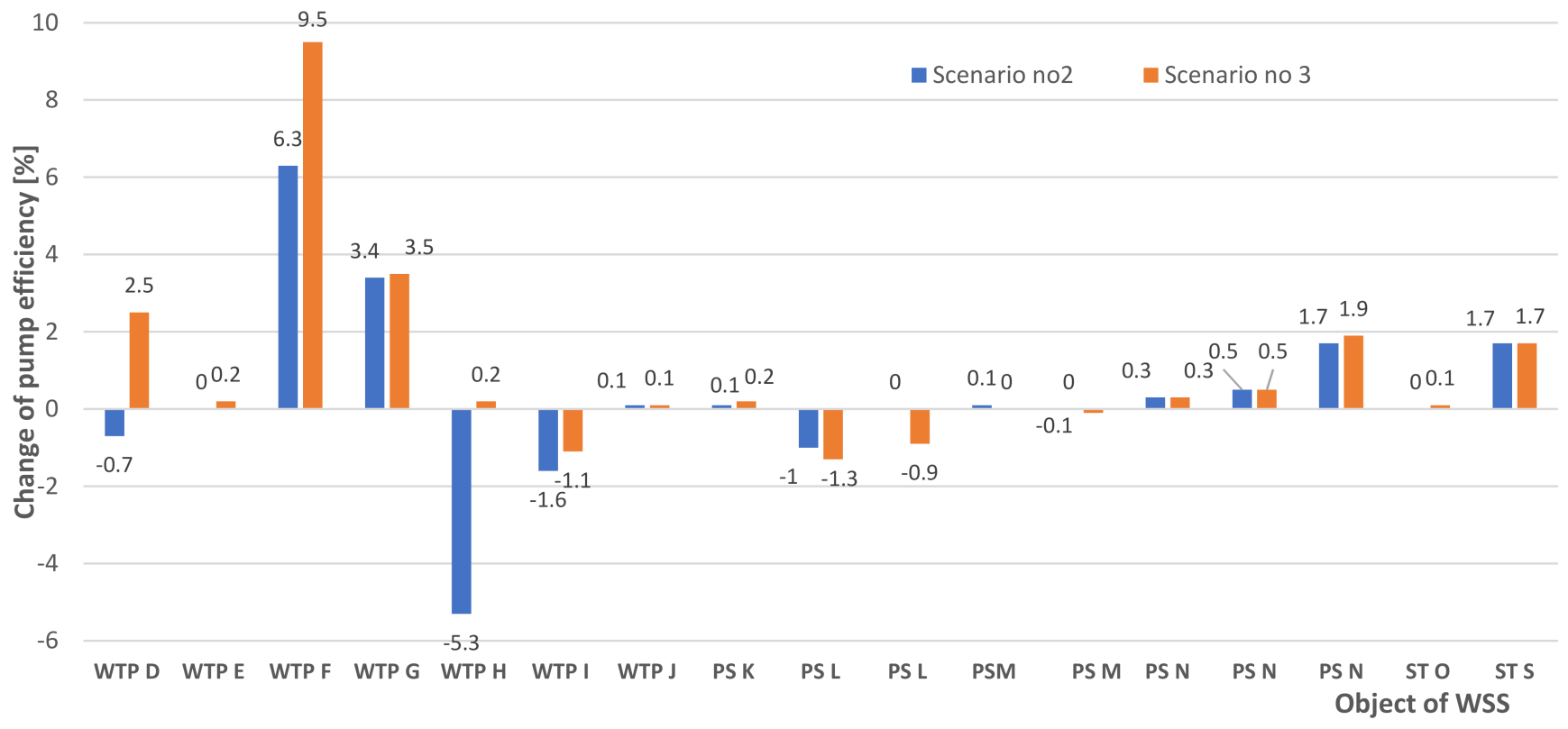

Figure 8. Change in pump efficiency in the analyzed pumps vs. Scenario no. 1 (WTP-water treatment plant, PS-pumping station, ST—storage tank).

The introduction of VFD in these facilities has resulted in a significant decrease in energy consumption. The obtained study results for the second scenario of the modification indicate that a proper integrated approach for the optimization of both energy and hydraulic efficiency in conventional water supply systems enables a significant reduction in energy consumption. This fact was emphasized by Vilanova and Balestieri $[26,39]$ in their study. In the literature, it is difficult to find descriptions and ways of dealing with the situation when, as a result of a crisis or other unforeseen events, a water supply system that 
was designed for very high flows has to operate at a much lower demand [8]. Therefore, it is necessary to look for savings at every level of the enterprise's functioning, including changes in the hydraulic system's management system. The proposed approach (Figure 9) can be adopted by other users of oversized water supply systems. To properly diagnose such situations, the first step is to collect a range of data, such as:

- The location and type of the following objects: junctions; reservoirs; tanks; pipes; pumps and valves;

- The amount of water input into the supply network;

- The amount of energy consumption used by the whole system;

- Pressure at individual pressure points and nighttime water flow.

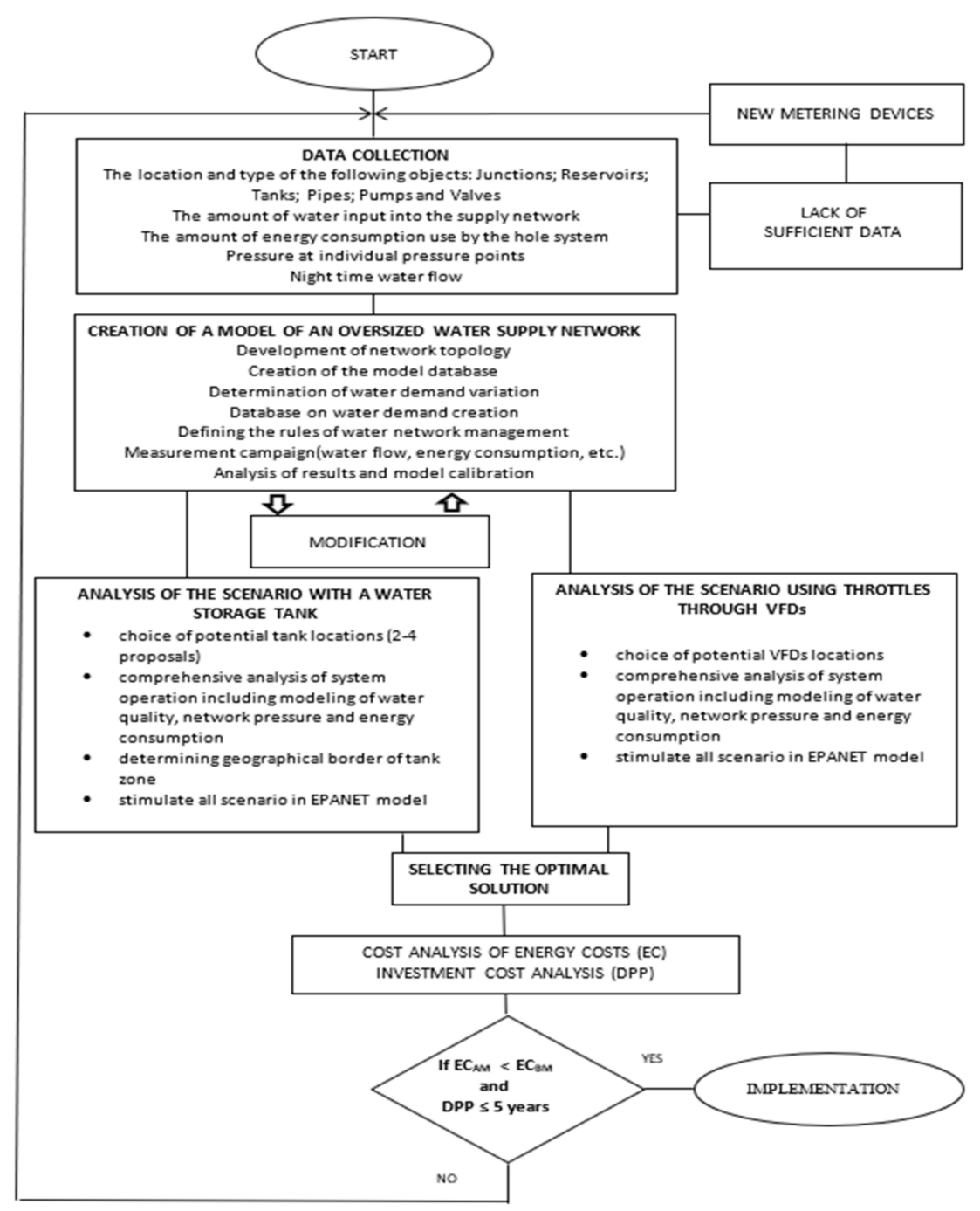

Figure 9. Flowchart of a comprehensive analysis of hydraulic and energy efficiency management and making rational decisions in oversized water supply systems $\left(\mathrm{EC}_{\mathrm{AM}}\right.$ - energy costs after modernization; $\mathrm{EC}_{\mathrm{BM}}$ - energy costs before modernization; $\mathrm{DPP}$ — discounted payback period).

Based on the collected data, a detailed model using the EPANET tool should be created. During the model creation, special attention should be paid to determining properly conducted measurement campaigns that allow for the correct calibration of the model. During calibration of the model, one should pay attention to at least two parameters, such as water flow and energy consumption. Conducting such activities, of course, requires that the system be properly equipped with measurement devices; this is the most difficult analysis. Therefore, the need for multiple modifications must be taken into account. A 
properly prepared and calibrated model allows a number of analyses to be performed to optimize the operation of the oversized system. In our experience, it may be useful to analyze two simple modifications presented in the paper as Scenario no. 2 and Scenario no. 3. After performing the analyses, the optimal solution at this stage should be selected and subjected to cost analysis, both from the point of view of energy consumption costs and potential investment costs to be incurred in connection with the implementation of the proposed scenario in the oversized system. If the electricity costs after the modification are lower and the payback period (DPP) does not exceed five years, one can decide to implement the scenario.

\section{Conclusions}

The analyses indicate the correct use of hydraulic models for the needs of energy management in an oversized WSS. With simulation models, it is possible to carry out many variations of oversized WSS's operation work, as well as its modifications. However, the simulations give results only of energy consumption at pumping stations; when making decisions about modernization, investment costs should be taken into account. Thus, hydraulic models can only be used as decision support systems. In some cases, operators may find that the changes required to improve energy efficiencies do not justify the capital expenditure required or are uneconomic to achieve.

The results of the conducted simulations can also be used to estimate the return on investment costs, e.g., by calculating the average energy consumption during the year. The ensuing analyses were the next phase of the research presented in this article. The work involved two simulations taking into account two modifications of the water supply system, indicating that it is possible to reduce energy consumption, even with small investment outlays (a slight reduction in energy consumption was obtained at the opening of the closed valves). The results of the conducted simulations indicate that the largest reduction of energy consumption was obtained after the introduction of VFD-type devices. This means that the pumps used are oversized. Modeling pumps with frequency inverters are not always associated with the use of these devices; in fact, they can be replaced with a smaller pump, or one can roll the rotor of the current pump to the required operating conditions (however, this solution will not give better results than the previous example because the old-generation pumps consume more energy). These two examples can also be analyzed using a simulation model by introducing new hydraulic curves for pumps, thus providing new results and new possibilities. The results also indicate that the net operational cost decreased when water pumps provided regulation reserves; furthermore, the operational feasibility of providing these reserves from water pumps is clarified, which is also confirmed by Negishi and Ikegami [47] and Chang et al. [48] in their study. Using the risk level in the water tanks may be crucial for cost reduction [49].

The presented study resulted in a flowchart (Figure 9), constituting an initial approach to the development of rational methods for reducing energy consumption in the oversized WSS, which should be verified in other water supply systems.

Taking the above into the account in the energy efficiency management system of water supply infrastructure, it is justified to include:

1. An inventory of the current state of the pumping system in terms of hydraulic requirements and energy consumption.

2. Analysis of the level of water losses accompanied by the identification of their source, analysis of water supply network failure rate, analysis, and classification of leakage levels (creation and ongoing maintenance of a database of failures and losses).

3. Use of numerical simulation model EPANET 2.0 for the selection of optimal operating parameters under changing conditions of the water supply system (maximal and minimal hourly water demands, maximal and minimal pressure).

4. Determination of critical operation zones of the water supply system, taking into account the optimization of pumping systems. 
5. Online monitoring of hydraulic parameters, including critical zones, and energy monitoring of pumping stations (creation and maintenance of a database of hydraulic and energy parameters).

6. Development of indicator limits for the operational decision-making system.

7. Ranking of investment needs in order to achieve the assumed energy effect.

The results of the presented research are of significant importance for the economy and society. The article is part of contemporary and current research trends focused on sustainable management, highlighting the importance of the issue of improving energy efficiency.

The presented work is only a fragment of research and analytical works that are conducted in order to limit water take-off and optimize the operation of an oversized system in terms of quality and pressure. A partial solution to this problem may be, apart from the reconstruction of oversized and technically worn parts of the network, the introduction of special cement, polyurethane, or PE liners inside the water supply pipes, which will ensure reduction of diameters and improvement of hydraulic conditions of the network. This problem will be discussed in future publications.

Author Contributions: Conceptualization, I.Z. and E.B.; methodology, I.Z. and J.M.-S.; software, E.B.; resources, J.M.-S., A.R. and S.R.; writing-original draft preparation, E.B. and I.Z.; writing-review and editing, I.K.-B. and A.R.; visualization, E.B. and I.K.-B.; supervision, I.Z. All authors have read and agreed to the published version of the manuscript.

Funding: This study was supported by the Ministry of Science and Higher Education of Poland within statutory funds-projects no BK-261/RIE4/2021; BKM-RIE4/2020 and the Rector's Habilitation Grant Silesian University of Technology, 13/040/RGH18/0066.

Informed Consent Statement: Not applicable.

Conflicts of Interest: The authors declare no conflict of interest.

\section{References}

1. Bluszcz, A.; Manowska, A. Differentiation of the Level of Sustainable Development of Energy Markets in the European Union Countries. Energies 2020, 13, 4882. [CrossRef]

2. Habek, P. CSR Reporting Practices in Visegrad Group Countries and the Quality of Disclosure. Sustainability 2017, 9, 2322. [CrossRef]

3. Dobrowolska, M.; Knop, L. Fit to Work in the Business Models of the Industry 4.0 Age. Sustainability 2020, 12, 4854. [CrossRef]

4. Lam, K.L.; Kenway, S.J.; Lant, P.A. Energy use for water provision in cities. J. Clean. Prod. 2017, 143, 699-709. [CrossRef]

5. Ramos, H.M.; Vieira, F.; Covas, D.I.C. Energy efficiency in a water supply system: Energy consumption and $\mathrm{CO}_{2}$ emission. Water Sci. Eng. 2010, 3, 331-340. [CrossRef]

6. Hiremath, R.B.; Shikha, S.; Ravindranath, N.H. Decentralized energy planning; modeling and application-A review. Renew. Sustain. Energy Rev. 2007, 11, 729-752. [CrossRef]

7. Carriço, N.; Covas, D.; Alegre, H.; do Céu Almeida, M. How to assess the effectiveness of energy management processes in water supply systems. J. Water Supply Res. Technol. 2014, 63. [CrossRef]

8. Klosok-Bazan, I.; Machnik-Slomka, J. Crisis management in small water supply companies—Problem with water quality. In Proceedings of the International Multidisciplinary Scientific GeoConference: SGEM, Albena, Bulgaria, 2-8 July 2018 ; pp. 179-185.

9. Zimoch, I.; Bartkiewicz, E. Optimization of energy cost in water supply system. E3S Web Conf. 2017, 22. [CrossRef]

10. Porsinger, T.; Janik, P.; Leonowicz, Z.; Gono, R. Modelling and Optimization in Microgrids. Energies 2017, 10, 523. [CrossRef]

11. Machnik-Słomka, J. Smart specialization as a factor stimulating innovative development of water and wastewater economy. E3S Web Conf. 2018, 59. [CrossRef]

12. European Council, Conclusions-23/24 October 2014; EUCO 169/14; European Council: Brussels, Belgium, 2014.

13. Directive 2009/28/EC of the European Parliament and of the Council of 23 April 2009 on the Promotion of the Use of Energy from Renewable Sources and Amending and Subsequently Repealing Directives 2001/77/EC and 2003/30/EC, L. 140/16; Official Journal of the European Union: Brussels, Belgium, 2009.

14. Directive 2012/27/EU of the European Parliament and of the Council of 25 October 2012 on Energy Efficiency, Amending Directives 2009/125/EC and 2010/30/EU and Repealing Directives 2004/8/EC and 2006/32/EC, L.315/1; Official Journal of the European Union: Brussels, Belgium, 2012.

15. European Commission: Accompanying the document Communication from the Commission to the European Parliament, the Council, the European Economic and Social Committee and the Committee of the Regions: A Policy Framework for Climate and Energy in the Period from 2020 to 2030; Official Journal of the European Union: Brussels, Belgium, 2014. 
16. Directive (EU) 2018/2002 of the European Parliament and of the Council of 11 December 2018 amending Directive 2012/27/EU on Energy Efficiency, L.328/210; Official Journal of the European Union: Brussels, Belgium, 2018.

17. Klosok-Bazan, I.; Boguniewicz-Zablocka, J.; Suda, A.; Łukasiewicz, E.; Anders, D. Assessment of leakage management in small water supplies using performance indicators. Environ. Sci. Pollut. Res. 2021, 28, 41181-41190. [CrossRef] [PubMed]

18. Matyjaszek, M.; Fidalgo Valverde, G.; Krzemień, A.; Wodarski, K.; Riesgo Fernández, P. Optimizing Predictor Variables in Artificial Neural Networks When Forecasting Raw Material Prices for Energy Production. Energies 2020, 13, 2017. [CrossRef]

19. Zimoch, I.; Bartkiewicz, E. Analysis of disinfectant decay in a water supply system based on mathematical model. Desalin. Water Treat. 2018, 134. [CrossRef]

20. Zimoch, I.; Bartkiewicz, E. Use of disinfection by-products (DBPs) generation simulation models in the risk analysis of secondary water contamination. Desalin. Water Treat. 2020, 199. [CrossRef]

21. Alegre, H.; Coelho, S.T. Infrastructure Asset Management of Urban Water Systems. In Water Supply System Analysis-Selected Topics; InTech: London, UK, 2012.

22. World Energy Outlook; International Energy Agency: Paris, France, 2016.

23. Enrique, C.; Pardo, M.A.; Ricardo, C.; Enrique, C. Energy Audit of Water Networks. J. Water Resour. Plan. Manag. 2010, 136, 669-677. [CrossRef]

24. Vilanova, M.R.N.; Balestieri, J.A.P. Modeling of hydraulic and energy efficiency indicators for water supply systems. Renew. Sustain. Energy Rev. 2015, 48, 540-557. [CrossRef]

25. Lenzi, C.; Bragalli, C.; Bolognesi, A.; Artina, S. From energy balance to energy efficiency indicators including water losses. Water Supply 2013, 13. [CrossRef]

26. Coelho, B.; Andrade-Campos, A. Efficiency achievement in water supply systems-A review. Renew. Sustain. Energy Rev. 2014, 30, 59-84. [CrossRef]

27. Walski, T.M.; Chase, D.V.; Savic, D.A.; Grayman, W.; Beckwith, S.; Koelle, E. Advanced Water Distribution Modeling and Management; Haestad Press: Waterbury, CT, USA, 2003; ISBN 978-0971414129.

28. Leon, A.S. Hydraulic Pumps; CWR 3201 Fluid Mechanics, Fall 2018; Florida International University. Available online: https: //www.coursehero.com/file/83726069/Pipe-Flows-Filledpdf/ (accessed on 11 August 2021).

29. Zimoch, I.; Szymik-Gralewska, J.E. Risk assessment methods of a Water Supply System in terms of reliability and operation cost. WIT Trans. Built Environ. 2014, 139, 12. [CrossRef]

30. Orazio, G.; Dragan, S.; Zoran, K. Pressure-Driven Demand and Leakage Simulation for Water Distribution Networks. J. Hydraul. Eng. 2008, 134, 626-635. [CrossRef]

31. Feldman, M. Aspects of Energy Efficiency in Water Supply systems. In Proceedings of the 5th IWA Water Loss Reduction Specialist Conference, Cape Town, South Africa, 26-30 April 2009; pp. 85-89.

32. Geem, Z.W. Harmony Search in Water Pump Switching Problem. In Advances in Natural Computation; Springer: Berlin/Heidelberg, Germany, 2005; pp. 445-449.

33. Variable Frequency Drive (VFD) for Pumps. Available online: http://www.gozuk.com/applications/vfd-for-pumps.html (accessed on 11 August 2021).

34. Nogueira Vilanova, M.R.; Perrella Balestieri, J.A. Exploring the water-energy nexus in Brazil: The electricity use forwater supply. Energy 2015, 85, 415-432. [CrossRef]

35. Rossman, L.A. EPANET 2: Users' Manual; National Risk Management Research Laboratory, Office of Research and Development, United Sates Environmental Protection Agency (EPA): Cincinnati, OH, USA, 2000.

36. Bylka, J.; Mróz, T. Exergy Evaluation of a Water Distribution System. Energies 2020, 13, 6221. [CrossRef]

37. Fooladivanda, D.; Taylor, J. Optimal pump scheduling and water flow in water distribution networks. In Proceedings of the 2015 54th IEEE Conference on Decision and Control (CDC), Osaka, Japan, 15-18 December 2015; pp. 5265-5271.

38. Oppenheimer, J.; Badruzzaman, M.; McGuckin, R.; Jacangelo, J.G. Urban water-cycle energy use and greenhouse gas emissions. J. Am. Water Works Assoc. 2014, 106. [CrossRef]

39. United States Environmental Protection Agency. Energy Use Assessment at Water and Wastewater Systems. Available online: https:/ /19january2017snapshot.epa.gov/sustainable-water-infrastructure/energy-use-assessment-water-and-wastewatersystems_html. (accessed on 11 August 2021).

40. Directive (EU) 2020/2184 of the European Parliament and of the Council of 16 December 2020 on the Quality of Water Intended for Human Consumption, L. 435/1; Official Journal of the European Union: Brussels, Belgium, 2020.

41. Energy Efficiency Best Practice Guide Pumping Systems; Victoria State Government: Melbourne, Australia, 2009.

42. Stringam, B.; Louisiana State University Agricultural Center; Louisiana Agricultural Experiment Station; Louisiana Cooperative Extension Service; Texas AgriLife Extension Service; New Mexico State University; University of Arkansas (Fayetteville campus), Division of Agriculture; University of Arkansas (System); Cooperative Extension Service. LSU AgCenter Pub. 3241-J: Pump Efficiency; Louisiana State University Agricultural Center: Baton Rouge, LA, USA, 2013.

43. Muranho, J.; Ferreira, A.; Sousa, J.; Gomes, A.; Marques, A.S. Technical Performance Evaluation of Water Distribution Networks based on EPANET. Procedia Eng. 2014, 70, 1201-1210. [CrossRef]

44. Da Gama Rego, A.; Pimentel Almeida Santos, A.C.; Rodrigues Pereira, J.A. Assessment of water pumping system and improvement in hydro-energetic performance. J. Urban Environ. Eng. 2017, 11, 42-50. [CrossRef] 
45. Bolognesi, A.; Bragalli, C.; Lenzi, C.; Artina, S. Energy Efficiency Optimization in Water Distribution Systems. Procedia Eng. 2014, 70. [CrossRef]

46. Pelli, T.; Hitz, H.U. Energy indicators and savings in water supply. J. Am. Water Works Assoc. 2000, 92, 55-62. [CrossRef]

47. Negishi, S.; Ikegami, T. Robust Scheduling for Pumping in a Water Distribution System under the Uncertainty of Activating Regulation Reserves. Energies 2021, 14, 302. [CrossRef]

48. Chang, Y.; Choi, G.; Kim, J.; Byeon, S. Energy Cost Optimization for Water Distribution Networks Using Demand Pattern and Storage Facilities. Sustainability 2018, 10, 1118. [CrossRef]

49. Luna, T.; Ribau, J.; Figueiredo, D.; Alves, R. Improving energy efficiency in water supply systems with pump scheduling optimization. J. Clean. Prod. 2019, 213, 342-356. [CrossRef] 